\title{
Clipping and precipitation influences on locoweed vigor, mortality, and toxicity
}

\author{
M.H. RALPHS, D.R. GARDNER, J.D. GRAHAM, G. GREATHOUSE, AND A.P. KNIGHT
}

Authors are Rangeland Scientist, USDA/ARS Poisonous Plant Lab, Logan Ut. 84341; Chemist, USDA/ARS Poisonous Plant Lab, Logan, UT 84341; Extension Agent, Union County Extension, Clayton, N.M. 88415; Ranch Manager, CSU Research Foundation Maxwell Ranch; and Chair, Clinical Sciences Dept., Colorado State Univ. , Ft. Collins, Colo. 80523.

\begin{abstract}
White locoweed (Oxytropis sericea Nutt. in T\&G) is widespread throughout the short-grass prairies and mountain grasslands and causes chronic poisoning of cattle, sheep, and horses. The objective of this study was to determine the effect of clipping (simulated grazing) on vigor, mortality and toxic alkaloid concentration of white locoweed. One hundred locoweed plants were marked at each of 3 locations (New Mexico, Colorado, and Utah). Plants were stratified into 2 age/size classes: young/small $<5$ stalks; older/large $>7$ stalks $(n=50$ in each class). Pairs of plants within each age class that were as similar as possible were selected, and 1 of each pair $(n=25)$ was clipped at ground level annually for 4 years. Vigor indices included number of stalks, number of flowering heads, leaf length, and flowering head height. Mortality was recorded and the toxic alkaloid swainsonine was measured. Clipping did not consistently reduce vigor. Flowering heads/plant declined in most clipped plants $(P<0.05)$, but stalks/plant declined only in large clipped plants in Utah and small clipped plants in New Mexico $(P<0.01$ ), and clipping did not greatly affect leaf length or flowering head height. Clipping did not increase mortality, and did not affect swainsonine concentration. However, there was a natural die-off that may have been related to precipitation. There were negative correlations between precipitation and locoweed mortality $(r=-0.42$ to -0.84$)$, with most of the marked plants dying during the recent drought. Grazing locoweed for short periods would likely not affect its vigor or toxicity, but its population dynamics were affected by drought.
\end{abstract}

Key Words: white locoweed, Oxytropis sericea, poisonous plant, population cycle

White locoweed (Oxytropis sericea Nutt. in $\mathrm{T} \& \mathrm{G}$ ) is the most widespread locoweed on western U.S. rangelands, and causes chronic poisoning in grazing livestock and wildlife. It is relatively palatable in the spring and fall when warm-season grasses are dormant, and signs of poisoning appear when animals consume it for 3-4 weeks. It inhabits shortgrass prairies along the foothills of the Rocky Mountains and high mountain grasslands, and typically occurs on shallow or rocky soils (Payne 1957, Ralphs and Cronin 1987). White locoweed is considered an increaser species (i.e. increasing in density as range condition declines from good to fair condition, but decreasing as excessive grazing pressure causes further deterioration from fair to poor condition, Payne 1957).

\footnotetext{
Manuscript accepted 14 Sept. 01.
}

\section{Resumen}

El "White locoweed" (Oxytropis sericea Nutt. in T\&G) esta dispersa a través de las praderas de zacates cortos y los zacatales de montaña y causa un envenenamiento crónico a los bovinos, ovinos y equinos. El objetivo de este estudio fue determinar el efecto del corte (apacentamiento simulado) en el vigor, mortalidad y concentración de alcaloides tóxicos del "White locoweed". Cien plantas de "White locoweed" fueron marcadas en cada una de 31 localidades (New Mexico, Colorado y Utah). Las plantas se estratificaron en dos clases de tamaño/edad: jóvenes/pequeñas < 5 tallos; grandes/viejas $>7$ tallos $(n=50$ en cada clase). Dentro de cada clase de edad se seleccionaron pares de plantas lo mas similares posible, $y$ una planta de cada par $(n=25)$ se cortó anualmente a nivel del suelo durante 4 años. Los indices de vigor incluyeron el número de tallos, número de inflorescencias, longitud de la hoja y altura de la inflorescencia. Se registró la mortalidad y se midió la concentración del alcaloide swansonina. EI corte no reduce en forma consistente el vigor. Las inflorescencias/planta disminuyeron en la mayoría de las plantas cortadas $(P<0.05)$, pero el número de tallos /planta se redujo solo en las plantas grandes cortadas en Utah y las pequeñas cortadas en New Mexico $(P<0.01)$ y el corte no afectó grandemente la longitud de las hojas y la altura de la inflorescencia. El corte no incrementó la mortalidad ni afectó la concentración de swansonina. Sin embargo, hubo una mortalidad natural que puede haber estado relacionada con la precipitación. Hubo correlaciones negativas entre la mortalidad de "locoweed"y la precipitación $(r=-$ 0.42 to-0.84), la mayoría de las plantas marcadas murieron durante la sequía reciente. El apacentamiento de "Locoweed" por periodos cortos de tiempo probablemente no afectaría su vigor o toxicidad, pero su dinámica de población fueron afectadas por la sequía.

Weeds that are not readily grazed have a competitive advantage over palatable grasses that are frequently defoliated. However, if animals could be forced to graze weeds, this additional stress may reduce their competitive ability and naturally reduce their stature and abundance in the plant community. Furthermore, on-off grazing (short intense periods grazing locoweed then removing the animals to allow for detoxification), has been proposed as a grazing strategy to reduce locoweed poisoning (Pfister et al. 1996). This type of a high-intensity, short-duration grazing system may force livestock to uniformly graze all forage in a pasture, thus increasing grazing pressure on locoweed. The objective of this study was to evaluate the influence of defoliation on the vigor, mortality and toxic alkaloid concentration of white locoweed. 
Weather data were available from nearby stations and correlations were made between precipitation and mortality to determine the influence of drought on these parameters.

\section{Methods}

Three locations were selected that had histories of cattle loss to white locoweed. The first site was $5 \mathrm{~km}$ west of DesMoines, New Mexico (N 36 45.23', W $103^{\circ}$ $\left.51.00^{\prime}\right)$, at an elevation of $2,200 \mathrm{~m}$. Soils were silty clay loam with interspersed outcroppings of volcanic basalt rock and a gentle southern exposure. Major grasses consisted of blue grama [Bouteloua gracilis (H.B.K.) Lag. ex Steudel], sideoats grama [B. curtipendula (Michx.) Torr.], little bluestem [Schizachyrium scoparium (Michx.) Nash], and western wheatgrass [Elymus smithii (Rybd.) Gould]. White locoweed was the dominant forb. Weather data were obtained from the Capulin National Monument, about $13 \mathrm{~km}$ from the study site.

The second site was on the Colorado State Univ. Research Foundation Maxwell Ranch, located $40 \mathrm{~km}$ northwest of Fort Collins, Colo. (N $40^{\circ} 54.73^{\prime}, \mathrm{W} 105^{\circ}$ $\left.16.33^{\prime}\right)$ at an elevation of $2,000 \mathrm{~m}$. Soils were a shallow gravely loam with a gently sloping west exposure. Associated grasses included needle-and-thread (Stipa comata Trin. \& Pupr.), squirreltail (Elymus elymoides Raf. Swezey), prairie June grass (Koeleria macrantha (Ledeb.) Schultes) and blue grama. Weather data were obtained from the Virginia Dale weather station $6 \mathrm{~km}$ from the study site.

The third site was on top of the Raft River mountains in northwest Utah ( $\mathrm{N} 41^{\circ}$ $55.61^{\prime}, \mathrm{W} 113^{\circ} 24.42^{\prime}$ ) at an elevation of $3,000 \mathrm{~m}$. Soils were shallow loam (10-25 $\mathrm{cm}$ to bedrock), with 35 to $65 \%$ coarse fragments. The plant community was dominated by alpine sagebrush (Artemesia scopulorum Gray), muttongrass (Poa fendleriana (Steud.) Vasey), and Idaho fescue (Festuca idahoensis Elmer). Weather data was obtained from the nearest station at Grouse Creek, about $25 \mathrm{~km}$ west of the study site and 1,200 $\mathrm{m}$ lower. The amount of precipitation would be greater at the study site, but the timing and pattern should be similar.

At each location, 100 white locoweed plants were marked by placing a numbered tent peg in the ground next to them. Plants were selected in 2 age/size classes: young/small $<5$ stalks; older/large $>7$ stalks ( $n=50$ in each class). The design attempted to separate effects of clipping on young, newly established plants, vs older plants that had been established for several years. Within each size class, pairs of plants were selected that were as uniform as possible. One of each pair $(n=25)$ was randomly selected and clipped at ground level each subsequent year during the flower stage of growth. The unclipped member of each pair served as a control. Indices of vigor included: number of stalks (equivalent to tillers in a grass), number of flowering stems, longest leaf length, and tallest flowering head height. Pinnately compound leaves of white locoweed and flowering stalks originate from the crown. Measurements were taken from the crown at ground level to the tip of the longest leaf and flowering head. Mortality was noted each year. All 3 sites were fenced to prevent grazing from livestock. There was no evidence of wildlife grazing within the exclosures.

The study began in June 1995 at New Mexico and Colorado when the plants were selected, measured, and those designated for defoliation were clipped. Because of logistic problems, the study did not begin in Utah until July 1996. All of the large clipped plants were dead at New Mexico in 1998. Most of the other marked plants at New Mexico and Colorado were dead in 1999. There were sufficient numbers of plants remaining in both size/treatment classes to analyze at Utah in 2000.

Because of the different start times and differing number of years plants that survived at each location, vigor data were analyzed separately for each location. Vigor indices were analyzed by a mixed model in SAS in a repeated measures design using compound symmetry covariate structure to compare the main effects of plant size (2) and clipping treatment (2) over years, and their 2- and 3-way interactions. Individual plants were experimental units.

Plant mortality was analyzed by failuretime analysis (Fox 1993). Mortality over time was compared among locations and between age classes using the Cox Proportional Hazards model in a log-log model using SAS Proc Probit. To standardize time, years were placed on a numerical scale ( 1 to 4 ) rather than calender years. Survival curves were used to display mortality over time.

Below average precipitation (drought) occurred in New Mexico in 1997 and 1998, in Colorado in 1998 and 2000, and in Utah in 1999 and 2000. Correlations were made between annual mortality and seasonal precipitation (fall, winter, spring, summer) or total water year precipitation to determine if there was a relationship between reduced precipitation and mortality. Annual mortality was expressed as the $\%$ of the original 25 plants in each size/ clipping treatment class that died each year. The Palmer Drought Severity Index (Palmer 1965) for each of the respective regions was graphed to illustrate the severity of drought during the study period (Fig. 1).

Concentration of swainsonine, the toxic alkaloid in locoweeds, was measured in the leaves of clipped plants. Individual plant samples from each year were extracted using the general procedures of Molyneux et al. (1991). Detection and quantitation of swainsonine was accomplished using atmospheric pressure chemical ionization mass spectrometry (APCIMS) (Gardner et al. 2001). Swainsonine concentration between small and large plants was compared the first year by oneway analysis of variance (ANOVA) within locations. There was no difference between size classes $(\mathrm{P}>0.05)$. Thereafter, only large plants were extracted because many of the small plants did not have enough dry plant material for accurate quantification of the alkaloid (1 g). Swainsonine concentration within individual plants over years and among locations was compared by a repeated measures mixed model using compound symmetry covariate structure. Locations and years were main effects and plants within locations and years was the repeated factor. In a separate analysis, swainsonine in clipped plants was compared to 8 control plants (not the paired plant) that were randomly selected each year from the surrounding area to determine if clipping affected swainsonine concentration. Data were analyzed separately for each location by ANOVA comparing clipped and unclipped plants over years. $\mathrm{P}<0.05$ was considered significant.

\section{Results}

\section{Vigor Indices}

There was a significant year-by-size interaction $(\mathrm{P}<0.05)$ for most indices at all 3 locations, therefore the statistical model was reduced and the 2 size categories were analyzed separately for each location).

\section{Stalks/plant}

The initial number of stalks on large plants was 7.6 at Colorado, 16.2 at New 

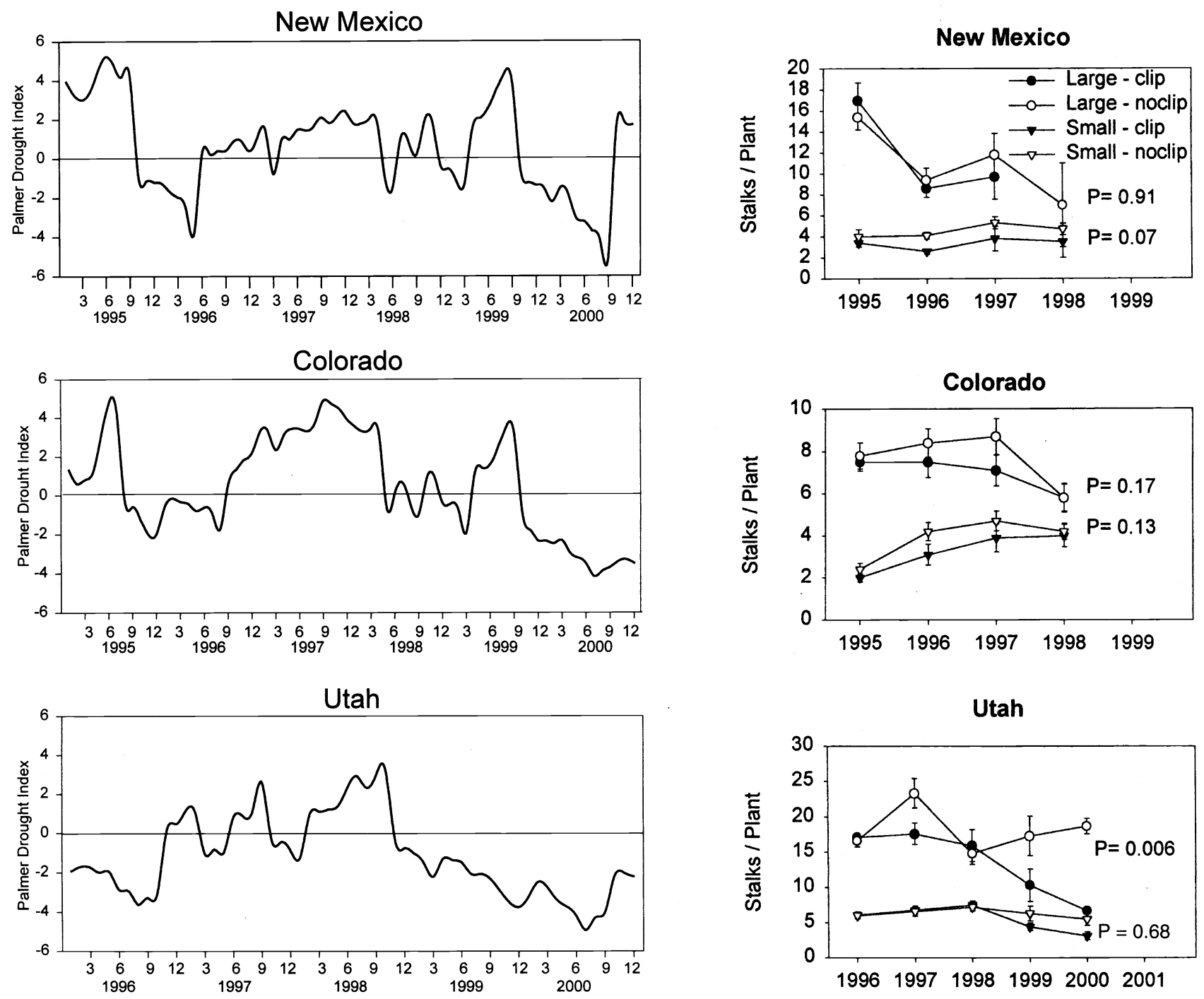

Fig. 1. Palmer Drought Severity Index for northeast New Mexico, north central Colorado, and north western Utah. Mild drought $\mathbf{- 1 . 0}$ to -2.0 ; moderate drought -2.0 to -3.0 ; severe drought -3.0 to -4.0 ; extreme drought $>\mathbf{- 4 . 0}$.

Fig. 2. The number of stalks/plant in large and small plants that were either clipped or not clipped at New Mexico, Colorado, and Utah over time. $P<0.05$ indicate differences between the clipped and non clipped plants in each size class.

Mexico, and 16.8 at Utah. The average number of stalks on small plants was 3.9 across locations, since the selection criteria for small plants was less than 5 stalks.

The main effect of clipping and the clip-by-year interaction was significant $(\mathrm{P}$ $<0.05$ ) only in large plants at Utah. The number of stalks on the large clipped plants at Utah declined from 16 to 7 over the study while the unclipped plants remained fairly constant (Fig. 2). The main effect of year was significant $(\mathrm{P}<$ 0.05 ) in both plant sizes and in most locations. At New Mexico, the number of stalks on large plants declined over time $(P=0.0001)$, but there was no difference between clipped and unclipped plants $(\mathrm{P}=$ 0.91). At Colorado and Utah, the number of stalks on small plants increased over years in both clipped and unclipped plants $(\mathrm{P}<0.0001)$, illustrating the growth or increase in number of stalks over time.

\section{Flowering Heads/Plant}

The initial number of flowering heads on large plants was 6.3 at Colorado, 20.2 at New Mexico, and 24.9 at Utah. The number of heads on small plants was 1.1, 0 , and 5.1 at the respective locations.

The number of flowering heads is a more sensitive measure of plant vigor than the number of tillers (stalks in this study) or leaf length (Mueggler 1972). The main effect of clipping tended to be significant $(P<0.10)$ in all sizes and locations except large plants at New Mexico, verifying that the clipping treatment reduced the number of flowering heads. The clip-by-year interaction was significant $(\mathrm{P}<0.05)$ for large plants at Colorado and Utah, and small plants at Utah. At Colorado, the number of heads on large clipped plants declined from 7 at the beginning of the study to 2 in 1996 , then increased to the level of the unclipped plants by 1998 (Fig. 3). At Utah, the number of heads of large clipped plants declined from 24 to 5 , and remained low for the remainder of the study. 

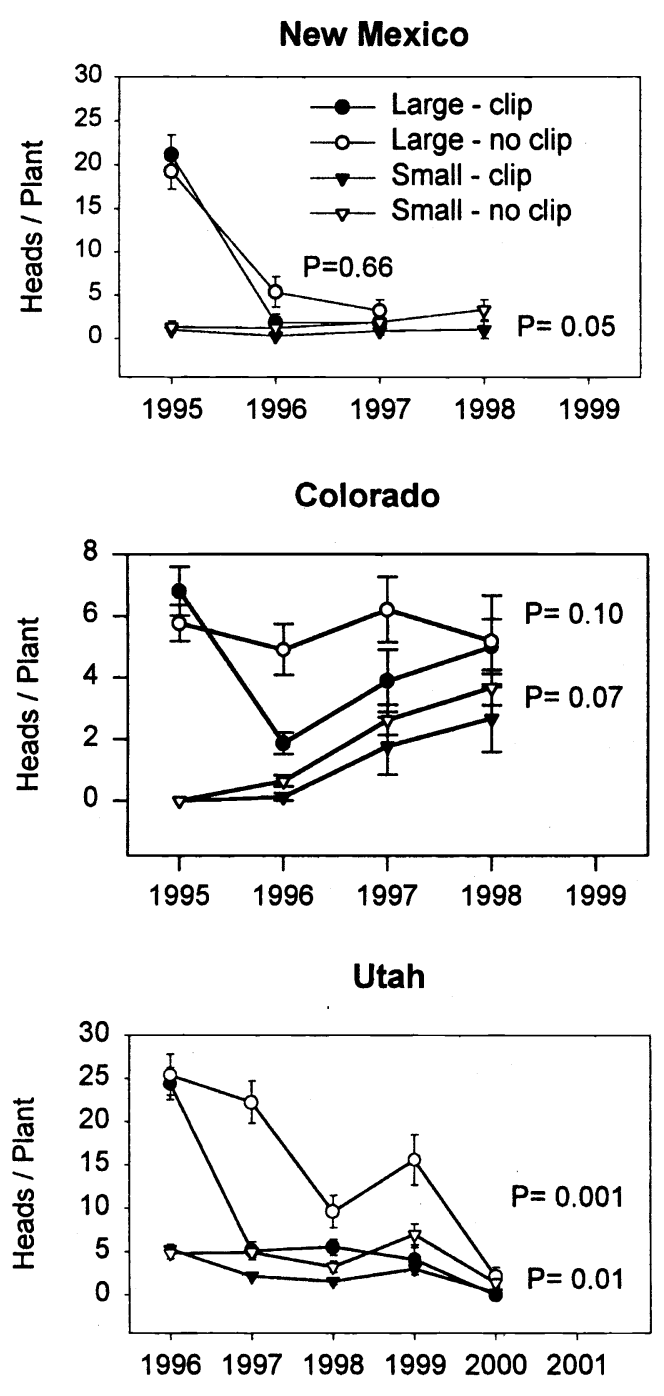
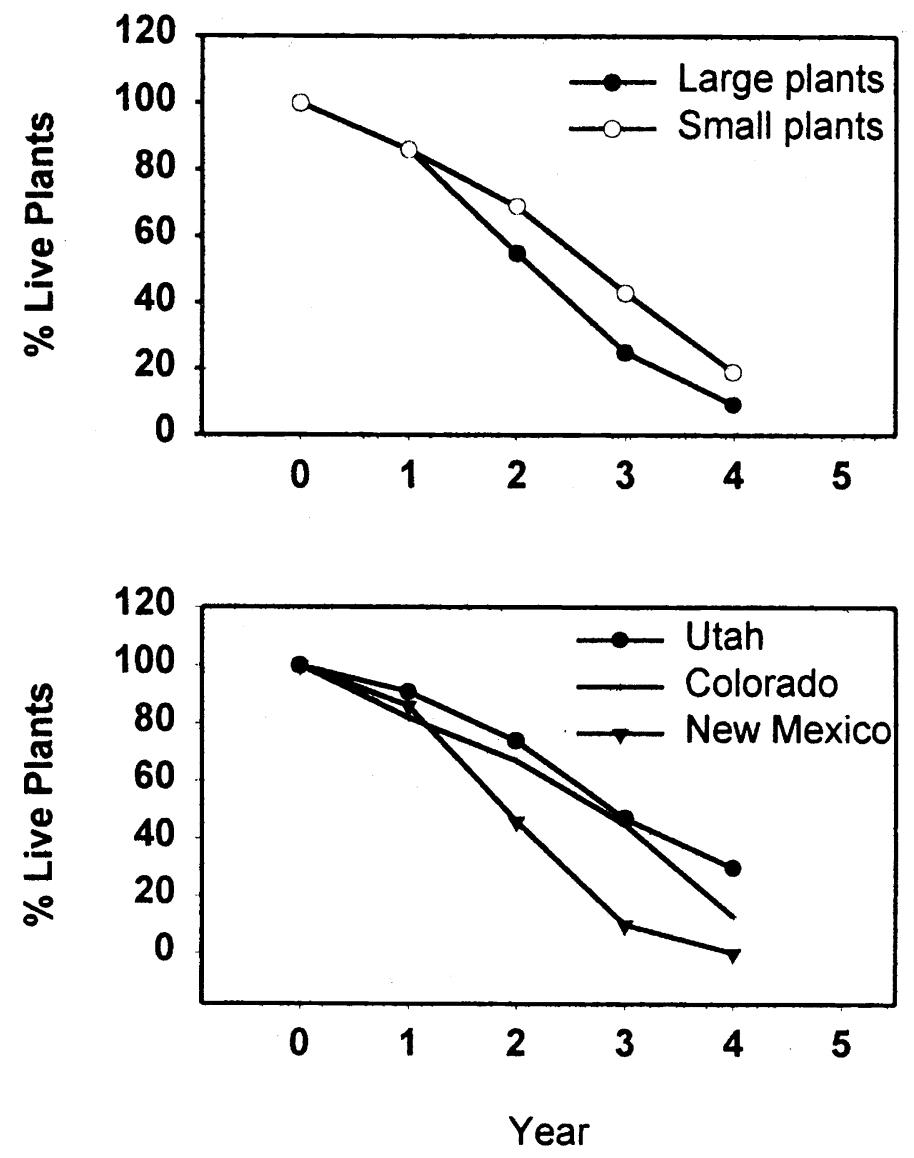

Fig. 3. The number of flower heads/plant in large and small plants that were either clipped or not clipped at New Mexico, Colorado and Utah over time. $P<0.05$ indicate differences between the clipped and non clipped plants in each size class.
Fig. 4. Locoweed mortality in large and small plants, and at 3 locations: New Mexico, Colorado and Utah.
Unclipped large plants declined gradually over the length of the study. The number of heads on small clipped plants at Utah declined in 1997 and 1998, and the number of heads in unclipped plants declined in 2000.

There was a strong year effect $(\mathrm{P}<$ 0.002 ) for both size plants and all locations. The number of heads in both clipped and unclipped large plants at New Mexico declined from 20 in 1995 to 5 in 1996. The number of heads of both clipped and unclipped small plants at Colorado increased over time.

There were some differences $(\mathrm{P}<0.05)$ in leaf length and head height at some locations, but they were slight and probably not large enough to influence the survival of the plants. Leaf length of large plants averaged $15 \mathrm{~cm}$, and was $11.4 \mathrm{~cm}$ for small plants; flowering head height averaged $19.6 \mathrm{~cm}$ over plant sizes and locations.

\section{Locoweed Mortality}

Clipping had no effect on mortality of locoweed plants at any of the locations ( $P$ $=0.93$ ). However, mortality over time was greater on large plants than on small plants $(\mathrm{P}=0.004)$ (Fig. 4). Mortality rate was greater at New Mexico $(\mathrm{P}<0.01)$; over
$50 \%$ of locoweed plants died following the winter and spring drought in 1996, and additional mortality occurred during the moderate droughts during the spring in 1998 and 1999 (Fig. 1). At Colorado, 84\% of small plants and $90 \%$ of large plants were dead after 4 years (Fig. 4), and the remaining plants died during the severe drought in 2000 (Fig. 1). Survival rate at Utah was higher $(\mathrm{P}<0.02)$ with $30 \%$ of the plants remaining after 4 years (Fig. 4). Although the mortality rate was not as great at Utah, the vigor measurements responded to the severe drought throughout 1999 and 2000 at Utah (Fig. 1).

Mortality was negatively correlated with 
Table 1. Swainsonine concentration in the same white locoweed plants clipped annually at New Mexico, Colorado and Utah $( \pm$ standard error of the mean).

\begin{tabular}{|c|c|c|c|c|c|c|c|}
\hline Location & 1995 & 1996 & 1997 & 1998 & 1999 & Mean & $\begin{array}{l}\text { Year } \\
\text { Diff. }\end{array}$ \\
\hline & $-\cdots$ & 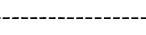 & ----- & Whiti) & 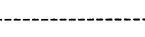 & ------ & -.---- \\
\hline NM & $0.11 \pm 0.01$ & $0.11 \pm 0.02$ & $0.07^{\circ} \pm 0.01$ & & & 0.097 & 0.07 \\
\hline $\mathrm{CO}$ & $0.04 \pm 0.01$ & $0.09 \pm 0.02$ & $0.06 \pm 0.02$ & $0.09 \pm 0.03$ & & 0.070 & 0.06 \\
\hline UT & & $0.07 \pm 0.01$ & $0.04 \pm 0.01$ & $0.03 \pm 0.01$ & $0.05 \pm 0.01$ & 0.048 & 0.05 \\
\hline
\end{tabular}

${ }^{\mathrm{l}}$ Mean difference within the same plant between years.

total water year precipitation at New Mexico ( $r=-0.84, p=0.008)$ and Utah $(\mathrm{r}=-0.75, \mathrm{p}=0.08)$. Correlation of locoweed mortality with summer precipitation at Colorado was not significant $(\mathrm{r}=$ $-0.42, \mathrm{P}=0.29$ ). However, the correlations were not totally accurate. High mortality in earlier years left few of the original marked plants in the experimental population, thus the mortality rate declined in the last year or 2. This reduced the strength of the correlations and underestimates the full impact of drought.

\section{Swainsonine}

Clipping had no effect on subsequent swainsonine concentration in locoweed plants $(\mathrm{P}=0.62)$. This is contrary to the Plant Defense Theory which suggests defoliation stimulates secondary defense compounds in some plants (Tallamy and Raupp 1991). There was also no difference in swainsonine concentration between large and small plants $(\mathrm{P}>0.05)$. There were differences among years $(\mathrm{P}<$ 0.07 ), but no recognizable trends (Table 1). There were differences among locations $(P=0.0001)$ with New Mexico having the highest concentration of swainsonine $(0.097 \%$ of dry wt), and Utah the lowest $(0.048 \%)$. Swainsonine concentration in a plant was not the same each year. Variability within the same plant over years was greater than the difference between locations (Table1).

\section{Discussion}

Clipping white locoweed in the flower stage for up to 4 successive years had only minor effects on vigor of the plants and did not affect mortality or swainsonine concentration. In tall larkspur (Delphinium barbeyi Huth), clipping at the bud elongation stage greatly reduced vigor and alkaloid pools for 2 subsequent years (Ralphs and Gardner 2001). Clipping other mountain forbs during the flowering stage was most detrimental to subsequent vigor (reviewed by Laycock 1975). Extensive research on rangeland grasses showed that clipping during anthesis was much more damaging than clipping during vegetative growth (reviewed by Caldwell 1984). Defoliation reduces photosynthetic capacity and root mass and retards the plants ability to extract water and nutrients from the soil. Neighboring plants use these resources, further reducing their availability. Thus, competition is the indirect factor causing reduction in subsequent vigor of clipped plants (Mueggler 1972). However, white locoweed has a deep tap root that extends below the rooting zone of grasses, and thus may not be subjected to direct competition for soil moisture. White locoweed does not appear to be adversely affected by annual defoliation in the flower stage or from competition from grasses.

Precipitation patterns apparently influenced white locoweed populations. Mortality occurred during the mild to severe drought periods at each of the locations. We found significant negative correlations between locoweed mortality and precipitation at New Mexico and Utah and weaker correlations with summer precipitation at Colorado. Our methodology of calculating mortality on marked plants without replacement may have limited the strength of the correlations. Furthermore, mortality of individual plants is determined by micro environmental conditions, which are difficult to estimate by seasonal weather measurements taken some distance form the study site.

Although white locoweed appears to be more persistent and longer-lived than many of the Astragalus locoweeds, our study showed that its populations still cycle. Marsh (1909) also observed that white locoweed was abundant in wet years, but nearly disappeared in dry years. Many of the semi-desert Astragalus locoweeds experience extreme population cycles that are driven by precipitation patterns (Welsh 1989). They germinate following autumn rains, remain green over winter, flower in spring, and may continue to grow for 1 or 2 years until the next drought occurs and the population dies back (A. lentiginosus, Barnes 1913; A. lentiginosus var. wahweapensis, Ralphs and Bagley 1988; A. pubentissimus, James et al. 1968).

Other factors besides drought may affect locoweed populations. The root-boring weevil Cleonidius trivittatus (Coleoptera: Curculionidae) prefer woolly locoweed (Astragalus mollissimus Torr.) and will kill the plant when 2 or more larvae occupy its root (Pomerinke et al. 1995). This insect and drought are major contributors to the crash of woolly locoweed populations. The insect is found to a lesser extent in white locoweed, but its influence on vigor and mortality is not known.

\section{Conclusions}

Clipping for 4 years did not consistently reduce vigor or increase mortality of white locoweed plants. Therefore, intensive grazing pressure, that would force consumption of white locoweed, would not likely reduce its population in the short term. There was a die-off of locoweed plants at all 3 locations that was associated with drought. The larger, and presumably older plants, had a slightly higher mortality rate, but a majority of small plants also died over the study. Clipping had no effect on subsequent toxicity of white locoweed.

\section{Literature Cited}

Barnes, W.C. 1913. Western grazing grounds and forest ranges. The Breeder's Gazette, Chicago. $390 \mathrm{pp}$.

Caldwell, M. M. 1984. Plant requirements for prudent grazing. pp. 117-152, in: Developing Strategies for Rangeland Management. Westview Press, Bolder Colo.

Fox, G.A. 1993. Failure-time analysis: emergence, flowering, survivorship, and other waiting times. pp. 253-289, In: S.M. Scheiner and J. Gurevitch (Eds) Design and Analysis of Ecological Experiments. Chapman \& Hall, New York. 
Gardner, D.R., R.J. Molyneux, and M.H. Ralphs. 2001. Analysis of swainsonine in locoweeds (Oxytropis spp.) Extraction methods and detection using liquid chromatography and tandem mass spectrometry. J. Agr. Food Chem. (in press).

James, L.F., K.L. Bennett, K.G. Parker, R.F. Keeler, W. Binns, and B. Lindsay. 1968. Loco plant poisoning in sheep. J. Range Manage. 21:360-365.

Laycock, W.A. 1975. Alkaloid content of duncecap larkspur after two years of clipping. J. Range Manage. 28:157-259.

Marsh, C.D. 1909. The locoweed disease of the plains. USDA Anim. Ind. Bull. 112.

Molyneux, R.J., L.F. James, K.E. Panter, and M.H. Ralphs. 1991. Analysis and distribution of swainsonine and related polyhydroxy indolizidine alkaloids by thin layer chromatography. Phytochem. Analys. 2:125-129.

Mueggler, W.F. 1972. Influence of competition on the response of bluebunch wheatgrass to clipping. J. Range Manage. 25:88-92.
Palmer, W.C. 1965. Meteorological Drought Res. Pap. No 45. U.S. Weather Bureau, NOAA Library and Info., Washington D.C. $58 \mathrm{pp}$.

Payne, G.F. 1957. Ecology and life history of the poisonous plant, white locoweed (Oxytropis sericea Nutt.). PhD Diss. Texas A\&M Univ., College Station, Tex.

Pfister, J.A., B.L. Stegelmeier, C.D. Cheney, L.F. James, and R.J. Molyneux. 1996. Operant analysis of chronic locoweed intoxication in sheep. J. Anim. Sci. 74:2622-2632.

Pomerinke, M.A., D.C. Thompson and D.L. Clason. 1995. Bionomics of Cleonidius trivittatus (Coleoptera: Curculionidae): native biological control of purple locoweed. Envir. Entom. 24:1697-1702.

Ralphs, M.H. and V.L. Bagley. 1988 Population cycles of Wahweap milkvetch on the Henry Mountains and seed reserve in the soil. Great Basin Natur. 48:541-547.
Ralphs, M.H. and E.H. Cronin. 1987. Locoweed seed in soil: density, longevity, germination and viability. Weed Sii. 35:792-795.

Ralphs, M.H. and D.R. Gardner. 2001. Influence of defoliation on toxic alkaloid concentration and alkaloid pools in tall larkspur. J. Chem. Ecol. (In press).

Tallamy, D.W. and M.J. Raupp. 1991. Phytochemical Induction by Herbivores. John Wiley \& Sons, New York.

Welsh, S.L. 1989. Astragalus L. and Oxytropis DC.: definitions, distributions, and ecological parameters. pp. 3-13, In: L.F. James, A.D. Elbein, R.J. Molyneux, C.D. Warren (eds.), Swainsonine and Related Glycosidase Inhibitors. Iowa State Univ. Press. Ames Ida. 